\title{
KÜLTÜREL BELLEKTE ASKERE YOLLAMA GELENEĞİ: BASKILL (ELAZIĞ) VE ÇEVRESİ ÖRNEĞİ
}

\author{
Doç. Dr. Ebru ŞENOCAK*
}

Öz: Baskil, kültürel değerlerin canlı bir şekilde yaşatıldığı Elazı ̆̆’’n önemli ilçelerinden birisidir. Halkın geleneksel değerlerine sahip çıkması, bölge kültürünün uzun yıllar canlı kalmasını sağlamıştır. Yahya Kemâl "Ne harâbî ne harâbâtîyim / Kökü mazide olan âtîyim." diyor. Ata kültüne, tarihe ve kültürel değerlere olan bu köklü bağlllık, kimlik bilincine sahip bireyler yetiştirme açısından oldukça önemlidir. Gelenek, bir toplumda kutsal kabul edilen kültürel değerlerin, nesilden nesile aktarılarak süreklilik arz etmesidir. Her birey, ait olduğu milletin toplumsal mirasından taşıdığı değerlerle kolektif bilinçte ölümsüz kodlar oluşturur. Askere gitme de kutsal bir vatan görevi olup halk arasında geleneksel değerler ile kutsanmaktadır. Askerlik, baba ocağından ayrılan her gencin hayatında, değişim ve dönüşüm yaratan, bilinç oluşturma açısından önemli bir geçiş dönemidir. Halk arasında askere gitmeyen gence kız verilmemesi, askerliğin erginlenme mekânı olarak önemine işaret etmektedir.

Çalışmada, Baskil ve çevresinde askere yollama geleneğine bağlı ritüeller (genci üç defa yukarı firlatma, simit 1sırtma, askerin mektuplarında yumurta pişirip ona yedirme vb.) kültürel bellekteki önemi açısından ele alınarak sembolik olarak tahlil edilmiştir. Böylece geleneklerin oluşumunda mitolojinin ve inanışların önemi vurgulanmıştır.

Anahtar Kelimeler: Elazı ̆̆/Baskil, asker ocağı, sembol, mitoloji, kültürel bellek.

THE TRADITION OF SENDING OFF TO MILITARY IN CULTURAL MEMORY: EXAMPLE OF BASKIL (ELAZIĞ) AND ITS SURROUNDINGS

Abstract: Baskil is one of the important districts of Elazığ where cultural values are kept alive. The people's protecting their traditional values ensured that the culture of the region remained alive for many years. Yahya Kemâl says that "I am neither ruined nor reveller / I am the future whose root is in the past." This deep-rooted commitment to ancestor cult, history and cultural values is highly important for raising individuals who are aware of their identity. Tradition is the continuity of cultural values, which are accepted as sacred in a society, by being transferred from generation to generation. Each individual creates immortal codes in collective consciousness with the values $\mathrm{s} / \mathrm{he}$ carries from the social heritage of the nation to which $\mathrm{s} / \mathrm{he}$ belongs. Going into the army is also a divine national service and is blessed with traditional values among the people. Military service is an important transition period that creates change and transformation in the life of every young person who leaves the family

ORCID ID : 000-0001-5443-3504

DOI : 10.31126-akrajournal.767495

Geliş tarihi: 10 Temmuz 2020 /Kabul tarihi: 16 Ağustos 2020

*Frrat Üniversitesi İnsani ve Sosyal Bilimler Fakültesi Türk Dili ve Edebiyatı Bölümü Öğretim Üyesi-ELAZIĞ 
Doç. Dr. EBRU ŞENOCAK

home. Among the people, not giving a girl in marriage to the young man who has not performed his military service, indicates the importance of military service as a place of passage to adulthood.

In the study, rituals (throwing the young man up three times, to make him bite a bagel, baking eggs in the soldier's letters and make him eat, etc.) related to the tradition of sending off to military in Baskil and its surroundings have been handled in terms of their importance in cultural memory and have been analyzed symbolically. Thus, the importance of mythology and beliefs in the formation of traditions has been emphasized.

Key Words: Elazığ/Baskil, place for military service, symbol, mythology, cultural memory.

\section{Giriş}

Gelenek, bizi geçmişimize özümüze bağlayan, toplumca kabul görmüş ve süreklilik arz eden değerlerdir. Tarihi yapısı ve doğal güzelliklerinin yanı sıra özellikle kayısısıyla, türbeleriyle, efsaneleriyle ve fikralarıyla halk kültüründe önemli bir yere sahip olan Elazığ'ın Baskil ilçesi, geçmişten gelen gelenekleri yaşatması yönüyle de dikkati çekmektedir. Uzun yıllara rağmen nesilden nesile aktarılan bilgi, töre, alışkanlıklar ve davranışların yaşatılması, kimlik bilincinin ifadesidir. Baskil'de hayatın geçiş aşamaları olan doğum, evlenme ve ölüme dair pratikler, ata kültüne bağl1lık ile uygulanırken geleneklerine bağlı gençler yetiştirilmesi dilenmektedir. Türk toplumlarında askere/peygamber ocağına gitme de önemli bir ara geçiş aşaması olup Baskil yöresinde konuyla ilgili pek çok geleneksel uygulama görülmektedir. "Bunların hepsinin amacı da askere gidecek kişinin yeni durumunu belirlemek, kutsamak, aynı zamanda askere gidecek kişiyi askerlikte yoğunlaştığına inanılan tehlikelerden ve zararlı etkilerden korumaktır. Askere yolcu etme ve karşılama çevresinde kümelenen âdetler, gelenekler, törenler ve bunların içinde yer alan işlemler ve uygulamalar o yörenin geleneksel kültürünü de yansıttığı için önemlidir.” (Artun, 2000: 47). Kültürün devamlılığını sağlayan gelenekler, geçmiş ve gelecek arasında köklü bağlar kurmaktadır.

Hayatı destan yazmakla geçen bir toplum olarak Türk milleti ata kültünden bugüne vatan, millet, devlet, savaşçılık, savaş aletleri gibi kavramlara önem vermiştir. Vatanını ve milletini en zor şartlar altında bile koruyan, milletinin refahını canından üstün tutan askerimize/Mehmetçiğimize minnettarız. Bir milletin dünya üzerinde var olabilmesi için savaşçılığının yanı sıra dil, din, tarih, kültür vb. değerlerine sahip çıkması gerekir. "Bellek ve hatırlamanın öznesi her zaman tek tek bireylerdir ama onlar anılarını kurgulayan 'çerçeveye' bağımlıdırlar." (Asmann, 2001: 40). İnsan ve iletişimde bulunduğu toplum, geçmişin kutsal anılarını hafızalarda güncellediği sürece canlı kalmaya devam edecektir. Türk toplumunda askerliğini/vatan görevini yapmış olmak halk arasinda gurur kaynağı olarak görülmekte olup her gencin vakti gelince askerliğini yapması istenir. Baskil yöresinde askere uğurlama ve askerden dönen genci karşılama esnasında yapılan ritüeller, halk arasında geleneğin canlı bir 
şekilde yaşatıldığını göstermektedir. Mitolojik dönemden bugüne sembolik anlamda pek çok değeri içinde barındıran bu gelenekler, inanışların gücüyle kutsallık taşımaktadır. Konu şu alt başlıklar hâlinde ele alınabilir:

\section{Askere Yollama Esnasında Yapılan Geleneksel Uygulamalar}

Geleneklerine köklü bir şekilde bağlı olan Elazığ/Baskil halkı arasında askerlik görevi, vatan borcu olarak nitelendirilmekte olup evlenmeden önce mutlaka askerliğini yapmış olmak gerekir. Askerlik hayatın önemli geçiş aşamalarından olup askerliğini yapmayana kız verilmemesi, askerliğin önemli bir erginlenme aşaması olduğunu göstermektedir. Genç kızın askerliğini yapmış bir genç ile evlendirilmesi, onun yalnız kalmasını engellemenin yanı sıra vatan görevini yapmış olmanın gururu ve gencin olgunlaşma süreci açısından oldukça önemlidir. Askerliğini yapmayan gence, kı istenildiği zaman; "Askerlik bitince düşünürüz." denilerek kız isteme talepleri uygun bir ifadeyle geri çevrilir. Özellikle ailenin reisi olan kız babası, kızını isteyen gence askerliğini yapmamış ise; "Askerliğini yapsın da biraz aklı başına gelsin.”, "Biraz burnu sürtülsün, büyüsün, hayatı öğrensin.” gibi sözlerle düşüncelerini iletir. Genç, askerliğini yaptıktan sonra kız ve oğlanın kararına göre evlenmelerine izin verilir. Bu anlamda askerlik, çocukluktan ergenliğe geçiş dönemi olup önemli bir aşamadır.

Asker, kutsal görevine uğurlanırken ailesi ve yakınları tarafından ona bir takım hazırlıklar yapılır. Bunlar öncelikli olarak gencin askerde kullanacağı iç çamaşırı, içlik, çorap, eldiven, yün çorap vb. türden giyim hazırlıklarıdır. Askerlik görevini yapacağı sırada ihtiyaçlarını karşılaması için kendisine el dokuması cüzdan içerisinde bir miktar para verilir. Askere gidecek olan genç, askerlik zamanı yaklaşınca serbest bırakılır, çalıştırılmaz. Arkadaşlarıyla daha fazla zaman geçirir, gezip tozar. Askere gitmesine 10-15 gün kaldığında akrabalarına, dostlarına veda ziyaretleri yapar. Onlardan helallik alır. Yakın akrabalarını ziyaret eder. Bu ziyaret sırasında akrabaları kendisine harçlık/para ve gömlek, iç çamaşırı gibi hediyeler verirler. Haklarını helal ettiklerini söylerler. "Hayırlı tezkereler.", "Tez zamanda git, gel.", tarzında iyi dileklerde bulunurlar. Asker olacak genç son gün, arkadaşlarıyla zaman geçirir, birlikte eğlenirler, yemek yer ayrılırlar (Kızılaslan, 2019: 70-71). Kutsal göreve uğurlanacak olan gencin hazırlıkları Anadolu'nun her yöresinde ve Türk dünyasında da benzeri olarak görülmektedir. "Tatar Türklerinde asker uğurlama merasimlerinde, asker adayları bütün köyü dolaşır, vedalaşırlar. Adaylara mendil ve havludan hediyeler verilir. Sevdikleri kızlar onlar için özel mendil ve havlu hazırlarlar. Birlikte şarkılar söylenir. Askere giden gencin ailesi oğullarının askere gittikleri gün komşularını yemeğe davet ederler. Helallik ve hayır dua alınır. Kadınlar mevlüt okuturlar.” (Kalafat, 2006: 19). 
Baskil halkı arasında askere gitmeden önce genci, akrabaları evlerine davet edip ziyafet verirler. Yapılan davette asker olacak kişi ile nasihat ve moral yükseltici sohbetler yapılır. Bunlar; "Sayıl zaman gelip geçer.", "Şimdiden hayırl tezkereler.", "Zaman su gibi akar.", "Sana verilen görevi hakkıyla yap.", "Göreve ihanet, vatana ihanettir." gibi ifadeler çerçevesinde yapılan sohbetlerdir. Bu arada askere gidecek gencin arkadaşları da asker olacak arkadaşlarına bir moral gecesi düzenlerler. Bu gecede, hazırlanan yemekler yenilir, türküler söylenir ve oyunlar oynanarak eğlenilir." (Kıyak, 2005: 59-60).

Asker kutsal vatan görevine uğurlanırken Türk bayrağı ile süslenen arabalarla götürülür. Şehit kanlarıyla sulanan kutsal vatan toprağından rengini alan Türk bayrağ1, al rengiyle al/ocak ruhunu, güç ve koruyuculuğu sembolize eder. Al rengin koruyucu gücü, kırmızı tülbent ile de yaşatılır: "Askere giden kişinin boynuna kırmızı oyalı tülbent bağlanır.” (Öz, 2015: 24). Askerin ailesi, onu kötü güçlerin olumsuz enerjilerinden korumak için al renkli tülbent boynuna takar. “Avşar Türk halk inançlarına göre al/kırmızı renk 'göz kaytarar' bed nazarların yansımasını sağlar. Al giyinen insana nazar değmeyeceği inancı vardır." (Kalafat, 2012a: 55). Şamanist inanışların etkisi ile günümüzde yaşayan al renge bağlı uygulamalar, doğum ve evlilik aşamasında da görülür. "Bu renk ile ilgili detayları doğumda al basmaması için annenin başına sardığı veya yastığının altına koyduğu kırmızı kumaşta, kötü ruhlar rahatsız etmesin ve evlilik daim olsun diye gelinlerin bellerindeki kırmızı kuşakta, başlarındaki al örtüde görürüz.” (Çelepi, 2017: 274). Şamanların Tanrı'ya kurban ayinleri düzenlerken giydikleri özel elbiseleri kırmızı renkli olup onun enerjisi ve gücüyle kötü ruhlar uzaklaştırılırdı. Al renk aşama geçiren kişiler için, kötü ruhlardan koruyan bir özelliğe sahiptir. Kırmızı renk aynı zamanda kurban kanı akıtmayı çağrıştırmakta olup kırmızı oyalı tülbent ile askerin vatana kurban edilmesi/adanması anlamını taşır.

Gencin askere gideceği veya askerde olduğu taşıt yazılarıyla çevreye duyurulur. Bu yazılar, askerin/Mehmetçiğin vatan ve milletin refahının, canından çok daha önemli olduğuna dair düşüncelerini dışa vurur. Ayrıca taşıt yazılarıyla, halkın kutsal vatan toprağı, asker, milliyetçilik vb. üzerine duygularının toplumla paylaşılması sağlanır. Konuya; "O şimdi asker”, "Askerin emaneti", "Biz babamızdan kalan $200 \mathrm{~m} 2$ arsayı kardeşler arasında paylaşırken bile kavga ediyoruz... Size toprak mı veririz.”, "20 yıl ben oynadım, 15 ay kader oynasın. O şimdi Elazığ”, "Gençliğini yaşamadan bu vatan uğruna canını feda eden şehitlerindir bu ülke!”, “Vatan sağ olsun.”, "Vatan bize minik size emanet." gibi sözleri örnek olarak verebiliriz.

Genç, askere uğurlanırken kendisine verilen eşyaların ve yapılan uygulamaların sembolik anlamları vardır. Baskil ve çevresinde görülen konu ile ilgili 
örnekler şöyledir: "Asker, gideceği sabah evinden alınır, ona memleketi gezdirirler. Ardından dualar edilir ve ağlamaması için eline emzik tutuşturulur." (K3). Emzik, bir sembol olarak kendi ayakları üzerinde duramayan ve anneden kopamayan bir çocuğu ve çocuksu davranışları ifade eder. Asker gencin, baba ocağından ayrıldığında onun çocuk gibi ağlamaması ve korkmaması dilenirken kendisine, olgunluğa doğru atacağı adımlar hatırlatılır.

Askere uğurlama ritüellerinde farklı bir uygulama şöyledir: "Askere giden kişiye ailesi tarafından bütün simit ısırtılır ve o şekilde duvara asılır. Askerden gelene kadar da bu şekilde bekletilir. Amaç, askerden să̆ salim gelip yediği nimeti ailesiyle tekrar yemek nasip olsun diyedir." (K1). Simit, sembolik anlamda bolluk ve bereketi ifade eder. Simidin bütün olması ise parçalanmamışlık ve bir arada olma dileğidir. Simit, yuvarlak şekil verilerek hazırlanan bir nimettir. Yuvarlak şeklin de sembolik olarak değerlendirilmesi gerekir. Van Gogh ve Joe Bousquet'e göre "Yaşam yuvarlaktır." (Bachelard, 2008: 329). Tasavvuf felsefesinde yaşam, devir nazariyesi ile açıklanır. Her varlık için hayat, yuvarlak bir çemberin başlangıç noktasında başlayıp, bitiş noktasında yeniden başlayan manevi bir yolculuktur. Mutlak varlıktan tecelli ederek ayrılan her ruh, çeşitli aşamalardan geçip değişerek madde mertebesine iner. Sonra yükselerek çeşitli merhalelerden geçer ve yine Allah'a ulaşır. "İçi dolu yuvarlaklığa ilişkin imgeler, kendi üstümüzde toplanmamıza, kendimize bir ilk kuruluş oluşturmamıza, varlığımızı içerden, mahrem biçimde ileri sürmemize yardımcı olur. Çünkü içerden, dıştalık olmaksızın yaşanan varlık, yuvarlak olabilir ancak." (Bachelard, 2008: 332). Asker gence simidin/yuvarlak bir nesnenin 1sırtılma amacı, görevinden sağ salim döndügü zaman ona hayatın yeni bir başlangıç olacağını anlatmak olabilir. Askerlik, bir erginlenme aşaması olup gencin olgunlaşarak bireyleşmesini, sorumluluk sahibi olmasını ve hayata daha farklı bakmasını sağlar.

"Bazen de askere gidecek olan kişiye bir simidin yarısı yedirilir, geriye kalan diğer yarısı da evde bir yerde saklanır. Sonunda bu iki ayrı parça nimetin birbirine kavuşacağı inancına bağlı olarak askerin eve sağ salim döneceğine inanılır (Çetintaş, 2010: 51). Buradaki uygulamada yuvarlak simidin iki eşit parçaya bölünmesi, eski sağlık ve sıhhatin yaşamın diğer yarısında devam etmesinin ifadesi olabileceği gibi iki parçanın birleşerek eksiğin tamamlanması olarak anlam kazanmaktadır. Yaşamın yuvarlaklığı içerisinde her aşama, yeni bir sınavdır. Tecrübelerin ve sınavların oluşturduğu zihinsel ve bedensel dönüşümler bireye güç kazandırırken onu yeni başlangıçlara hazırlamaktadır.

Simidin undan yapılmış olması, nimet olarak kutsallığını arttırmakta olup benzeri uygulamalar şöyledir: "Askere gidecek olan kişinin başında ekmek kır1lırd1.” (K5). Askere gidecek gencin annesi bir tabak köy değirmeninde öğütülmüş tam buğday ununa elini batırıp oğlunun başına sürerken "Allah seni 
belalardan korusun, săglıkla götürüp să̆lıkla getirsin. Kulluğun Allah'a, kurbanlığın Allah'a olsun." der. Başa sürülen bu un, daha sonra sadaka olsun diye muhtaç birine verilir (K2). Yapılan uygulamalarda, ekmek/un ile genci kutsama ve felâketlerin önüne geçilmesini umut etme bizleri mitolojik kökene götürür. Un ve undan yapılan ekmek, simit vb. her şeyin yere düşürüldügü zaman günah, çarpılırız düşüncesiyle besmele çekilerek hemen yerden alınması, öpülerek alına götürülmesi onu gizemli kılar. Mitler, dinsel deneyimler içerdiği için ilkel dönemden bugüne farklı bir anlam değerine sahip olmuştur. Toprak ve suyun yeşerttiği tohum/tahıllar verimlilik, bolluk ve bereket temasıyla ekim/hasat zamanlarında törenler ile kutsanmış hatta onlara kurbanlar sunulmuştur. Av merasimleri veya savaş öncesi buğday, arpa vb. tahıllar ile kutsamalar yapılmış, kıtlığı kovma, başarılı olma, bereket ile savaştan dönme, kötü ruhlardan ve felaketlerden korunma dilenmiştir. Kutsal nesnelerle yapılan mitik ritüeller, günümüz Türk dünyasında ortak bir kültür unsuru olarak geçiş aşamalarında yaşatılmaya devam etmektedir. Askere yollama geleneğinde gencin başında ekmek kırılması benzeri olarak Elya/İlya aşiretinde görülür. "Çocukların başına sıcak ekmek kırılır. Bu uygulamadaki amaç çocukları nazar ve benzeri belalardan korumaktır. Başına sıcak ekmek kırılan kimsenin yedi beladan korunduğuna inanılır." (Kalafat, 2012c: 80-81). Askere giden gencin başında ekmek kırılırken de onun her türlü felaketten korunması ve rızkının bol olması dilenmiştir.

Türk dünyasında ekmek, un, arpa, buğday vb. ile kutsama ritüellerinin pek çok örneğine rastlanılmaktadır. "Özbekistan'da bebeğin tırnağı kesilmeden (Buhara ve Semerkant'ta) çocuğun eli ekmek yapılacak una batırılır ise bebeğin rızkı olacağına inanılır. Una el batırmak suretiyle bereketi celp etmek Makedonya, Anadolu ve Suriye Türklerinde de vardır. Anadolu'da gelin attan inmeden evin damında bekleyen damat, gelinin başına çerez, para, buğday atar. Şam yöresi Türkmenlerinde yeni gelinin ayağının bereketini ölçmek için, gelinin eline eşikten geçmeden evvel verilen hamuru evin duvarına atması istenir. Hamur duvara yapışır ise gelinin ayağının bereketine inanılır." (Kalafat, 2012b: 233-252). Tatar Türklerinde arış “ekmeğin kesilen baş kısmı” tavana konur. Tavanda saklanır.” (Kalafat 2006: 19). Kültürel bellekte yaşatılan bolluk, bereket, korunma vb. amaçlı ritüeller bizleri, mitolojik kökene götürmektedir. "Bir yı̆̆ın dramatik sahnede biçimlenen basit ya da karmaşık ritüeller, insan ile bu "güçler" arasında yararlı ilişkiler kurmayı amaçlar; böylece güçlerin düzenli olarak yenilenmesi sağlanır." (Eliade, 2003: 328). Ekmeğin/unun dokunulmazlığına bağlı olarak bu kutsal nesnelerle yapılan ritüeller, kişiyi ilk oluşum zamanına ulaştırırken bütünlük içinde geçirilecek verimli ve bereketli günleri çoğaltma dilenmiştir. 
Halk arasında görülen farklı bir ritüel şöyledir: “Askere gidecek kişinin aç kalacağ1 zamanlarda yemesi için un ve pekmezden helva kavrulur. Helvadan küçük tekerlekler yapılır, her bir tekerlek bir yufkanın içerisine konularak askere gidecek kişinin çantasına bırakılır. (Helvadan hazırlanan bu tekerlekler bir- bir buçuk yıl bozulmaz, çünkü yufka ekmeği uzun zaman geçtiği için helvanın üstünde kuruyarak helvanın bozulmamasını sağlamaktadır.) Ayrıca içerisine helva konan bu yufka ekmekleri eğer askere gidecek kişi evliyse bir tane de eşine verilir. Eşi de bu yufkayı sandığında kocası askerden dönene kadar saklı tutar. Amaç, askere giden kişinin sağlıkla gidip gelmesi içindir. Kişi askerden döndüğünde ise hanımı sandıktaki ekmeği çıkarıp içindeki hel-vayı bölerek aile bireylerine dağıtır ve toplu bir şekilde yerler." (K2). Helva, doğumdan ölüme insan hayatının her aşamasında paylaşılarak yenilen bir tat-lıdır. Ağız tadının yerine gelmesini de ifade eden topluca helva yeme alışkanlığı, askerden sağ salim dönen gencin kutlamalarında kutsanır. Mitolojik dönemde kavrulan unun kokusu etrafa yayıldığında iyi ruhların memnun olması sağlanmaktaydı. Geçmişin kut merasimini bugünde güncelleyen gelenekler, İslamiyet sonrası dönemde ise hayır işleme, ölen kişinin ruhunu memnun et-me, onun sevaplarının artmasını dileme vb. amaçlarla kişi-Tanrı arasındaki bağı kuvvetlendirme açısından kutsallık arz etmeye devam etmektedir.

Anadolu ve Türk dünyasında görülen bir diğer uygulama, Baskil halkı arasında askere gideceği gece gencin parmağına kına yakılmasıdır (Kızılaslan, 2019: 70-71). Genellikle serçe (K3) veya tetik basacağı parmağına/işaret parmağına bazen de avuç içine kına yakılır. Türk örf ve âdetlerinde düğünlerde ve bayramlarda görülen kına yakma, askere giden gence de yakılır. Gelin giden genç kız evine/eşine, kurbanlık hayvanlar yüce Allah'a, baba ocağından peygamber ocağına giden asker de "Vatanına ve milletine kurban olsun." anlamında kınalanır. Sembolik anlamda saflığı ve temizliği ifade eden kına, yeşil renkte olup yakıldığı zaman al renge dönüşür. Yeşil ve al renk muradın/nurun ve adanmışlığın/kurban olmanın sembolüdür. "Arapça 'hına, hınnâ' kelimesinden dilimize geçen; Türk lehçelerinde de 'qına, kına' olarak kullanılan kına, tırnakları, elleri ve saçları boyamak için kullanılan bir bitkidir. Besleme, canlandırma, renk verme özelliği ile kozmetikte; parasetemol özelliğiyle de farmakolojide etkili olan kına, Hazreti Muhammed' in başı ağrıdığı zaman, kınayı ilâç niyetine başına sarması, herhangi bir yeri yara olduğu zaman pomad olarak kullanması ile de dinî misyona sâhiptir." (Eker, 1998: 25). Kâbe'den geldiğine inanılan kınanın askerin eline yakılması, gencin vatana adanmasının yanı sıra bilek gücünün artması ve manevi anlamda bütün felâketlere karşı korunması dileğini de ifade eder. 
Askere gidecek genci korumak için dualar ve âyet-i kerîmeler okunur, muskalar yapılır: Askere giden erkek bütün kötülüklerden, zararlı hayvanların 1sırmasından, sihir ve büyülerden, hastalıklardan ve gelecek kurşunlardan korunsun diye içerisinde duaların yazılı olduğu deriden bir muska yapılır. (K2). Askere gidecek olan kişi kurşunlardan korunsun diye bir ipe dua okunur, boynuna veya bileğine takılır (K2). "Başının gözünün sadakası olsun, başına kaza bela gelmesin." dileğiyle fakir ve fukaraya sadakalar verilir. (K1). "Askere gidecek olan kişiye Kurân-1 Kerîm'den iki âyet yazılarak biri ona verilir. Bu âyetlerin birinde Allah (C.C), diğerinde Hz. Muhammed (S.A.S)'in ismi yazılıdır. Peygamberimizin üzerinde ismi yazılı olan âyeti asker olana verilirken üzerinde Allah (C.C.) ismi yazılı olan âyeti ise evde bırakılır. Neticede Allah ile peygamberin birbirine kavuşacağı inancına bağlı olarak askerin de bu iki âyet vesilesiyle askerlikten sağ salim döneceğine inanılır (Çetintaş, 2010: 51). "Ana kucağ1, askere gidene "Peygamber ocağına gidiyor." derlerdi. Hoca camide ezan okuyarak kişi askere gönderilirdi." (Parlakkaya, 2020: 4). Söz konusu örneklerde, İslami inanışın etkisiyle âyetlerin, duaların ve ezan sesinin büyülü gücünden faydalanılmıştır. Askerin bu kutsal koruyucu kalkanlar ile sağ salim dönmesi dilenmiştir. İhtiyaç sahiplerine yardım edilerek onların duasıyla gencin zorlu günlerinde felâketlerden korunması ve sıkıntılarından kolaylıkla kurtulması amaçlanmıştır.

Askere gideceği gün, gencin arkadaşları ve akrabaları toplanarak konvoy hâlinde asker uğurlamaya giderler. Otogarda oyun havaları eşliğinde eğlenirler. "En büyük asker bizim asker!', “Bu asker gidecek, geri gelecek.” gibi sloganların eşliğinde, asker olacak genç havaya atılır, tutulur (Kızılaslan, 2019: 70-71). Askerin üç kez havaya atılması, İslamiyet öncesi Şamanist inanışın izlerini taşımaktadır. "Türk inanç sisteminde gök veya Kök Tengri (mavi gök) mühim bir yer tutar. Kişioğlu, göğün örttüğü, yağız yir (kara yerin)in taşıdığı ve yir-subların bulunduğu yeryüzünde kılınmıştır. Köktürk çağından önce ve sonra, gök bu koruyucu vasfı ile kutsanmış, 1duk kabul edilmiştir." (Kalafat, 1995: 34-35). En büyük Tanrı Bay Ülgen, göğün en üst katında oturmakta olup aydınlıklar âlemini temsil etmektedir. Askerin üç kez göğe atılması İslâmiyet öncesi dönem özelliklerini taşımakta olup onun, gökte yaşadığına inanılan Tanrı'nın kutsaması altında korunacağı düşüncesine dayanmaktadır. "Üç sayısı eski toplumlarda gök-yer-yer altı üçlemesi ile kutsaldı.” (Gökhan, 2009: 43). Şamanizmin üçlü evren anlayışını da hatırlatan bu uygulama, aşama geçirecek gencin kutsal yolculuğuna dikkat çekmektedir. Anadolu'da, mitolojik dönemden bugüne yaşatılan benzeri örnekleri görmek mümkündür. "Özel hallerde bebeklerin, gerdekten önce damatların, düğün bitmeden kaynananın, defnedilmeden önce meftanın Gök’e doğru hop-latılması, eski inançlarımızın halk 
arasındaki izleri itibariyle Gök’ün kutsallığı inancının hâlâ devam ettiği anlamında olabilir.” (Kalafat, 1995: 35). "Güney Anadolu yayla düğünlerinde, kına gecesi, gelin yastığa oturtulur ve üç defa yukarıya doğru kaldırılır. Kastamonu'nun Azdavay bölgesi Türkmenlerinde, gelinin erkek kardeşi, gelinin kuşağını bağlarken kuşağı üç defa kendi başının ve sonra üç defa da gelinin baŞının üzerinde havaya/göğe doğru kaldırır. Bütün bunlar Gök’teki bir güçten kut/güç alma isteğinin uygulamalarıdır." (Kalafat, 2013: 277-278). Söz konusu örnekler, geleneklerin oluşumunda inanışların, dinin ve mitolojinin önemli etkisi olduğunu göstermektedir.

Askere gidilecek günün sabahı, asker olacak gencin evinde yakınları ve dostları toplanır. Toplu eğlenceler esnasında davul, zurna, saz ve darbuka gibi çalgılar çalınarak askerlere moral verilir. Uğurlamalar yapıldıktan sonra asker ailelerine "Allah kavuştursun”, "Allah să̆ salim geri dönmeyi nasip etsin.” gibi dualar edilir. Son olarak genç, herkesle vedalaşır. Büyüklerin el-lerinden, küçüklerin gözlerinden öpüp "Allahaısmarladık” diyerek yola çıkar.

"Asker uğurlanırken arkasından su dökülür. Su gibi aziz olması için. Suyun kutsallığına da inanılır." (Parlakkaya, 2020: 51) "Giden askerlerin arkalarından gittiği gibi sağlıklı, sıhhatli ve çabuk dönsün diye sevdikleri tarafından su dökülür.” (Öz, 2015: 24). Su saflığın, ferahlığın ve arındırıcılığın sembolü olup yapılan uygulamalarda, askerin karşısına çıkacak engellerin suyla temizlenmesi, tez gidip tez gelmesi ve sağ salim evine dönmesi dilenmektedir. "Su, bütün potansiyel ve üretken güçleri temsil eder; sular tüm varoluşun kaynağ1dır." (Eliade, 2003: 196). Bayır-Bucak Türkmenlerinde de askerin ardından su dökülür. "Suyun aydınlık getireceğine inanılır. Askere gidenlerle helalleşirler, ardından hayır dua edilir." (Kalafat, 2013: 268). Suyun zamanı ve mekânı aşan bu sonsuz gücü, başa gelecek/gelebilecek bütün felâketleri silip yok edecektir. "Su, imgemizi doğallaştırmaya, içten seyrimizin onuruna biraz masumluk ve doğallık katmaya yarar." (Bachelard, 2006: 30). Suya bağlı ritüellerde suyun kutsallığı, arınmış gönüllerin kurduğu düşlere akıcılık, doğurganlık ve bereket vererek hayallerin gerçekleşmesine hız kazandıracaktır.

Asker ailesi, kurban kesip evlatlarının sağ salim dönmesini yüce Allah’tan diler. Kurban kanı akıtılarak askere giden gencin bütün kazalardan, felâketlerden korunması, olabileceklerin önüne geçilmesi istenir. Anne-baba, evlatları askerden sağ salim dönerse yine kurban keseceklerine dair adaklarda bulunurlar. "Kurban, genel olarak Allah'a manen yaklaşmak için dinin emri olan adak veya bir sevincin şükrünü yerine getirmek için kesilen hayvandır." (Özkan, 2003: 12). Tanrı'ya sadakat ile yapılan bu eylem, kişiyi manen Tanrı'ya yaklaştıracaktır. 
Asker uğurlanırken komşular gelip ailesine “Allah kavuştursun.” derler. "Askere uğurlama, eskiden uğurlama istasyonlarında davul zurna eşliğinde yapılırdı. Yöremize ait halk oyunları oynanır, halaylar çekilirdi." (K5). Gelişen çağa rağmen bazı yerlerde unutulmaya yüz tutsa da halk arasında geleneğe bağlı uygulamalar ayakta kalmaya devam etmektedir. Gencin gideceği gün halay çekilerek davul zurna çalınması da bu uygulamalar arasındadır. Ayıca askerin arkasından dualar edilip tekbirler getirilerek kutsal görevine uğurlandığ görülmektedir.

"Belleğin birlik sağlayıcı ve eyleme yönelik -kuralcı ve biçimsel- itkilerini yerine getirebilmesi için üç koşul gereklidir: Kaydetme, çağırma ve iletme; ya da şiirsel biçim, ritüel sunuş ve toplumsal katılım.” (Asmann, 2001: 60). Ritüeller, kültürel belleğin hafizalarda güncellenmesinde önemli bir işleve sahiptir. Toplu katılım ile yaşatılan değerler, toplumun kimliğini koruyucu bilgilerdir. Ata kültüne bağlılık ile nesilden nesile aktarılan bu uygulamalar, toplumsal bellek mekânlarını besleyici özelliğe sahiptir.

\section{Asker Karşılama Esnasında Yapılan Geleneksel Uygulamalar}

Asker uğurlanırken yapılan kutsama ritüelleri, genci karşılama esnasında da görülür. Eş, dost ve akraba ile gencin sağ salim dönüşü kutlanır, güzel duygular paylaşılarak çoğalır.

Askerin dönüşü esnasında aile arasında büyük bir sevinç ve mutluluk ortamı oluşur. Askerin geldiğini aileye ilk müjdeleyen kimseye aile tarafından bir hediye verilir. Bu arada asker de geldiği yöreden aile fertlerine bazı hediyeler getirir (Kıyak, 2005: 59-60). "Bazı ailelerde, çocuklara şeker dağıtılır." (Öz, 2015: 24).

Genç, askere gönderildiği gün olduğu gibi asker dönüşünde de kalabalık bir toplulukla karşılanır. Adak adanmış ise kurban kesilip dağıtılır. Askerin geldiğini duyan akrabalar da asker görmesine aileyi ziyarete gelirler. Hediyelerle ve dileklerle asker ailesine gözaydınında bulunurlar. Mevlitler okunur (Kızılaslan, 2019: 70-71). Askerin sevdiği yemekler ve tatlılar hazırlanır.

Askerden dönüşü sonrası ailede, genç hakkında evlilik konuşmaları dile getirilir. "Askerliğini bitirip eve dönmesinin üzerinden bir iki hafta geçince de hemen onun için ailesi münasip bir kız bulma derdine düşer. Gencin artık evlenme zamanı gelmiştir." (Öz, 2015: 24). Askerin döndügü gün yapılan şu ritüel, bir anlamda gencin evlendirilmesi ve çoluk çocuğa karışması gerektiğinin mesajını vermektedir. Gencin askerliği esnasında ailesine gönderdiği mektuplarını ailesi saklar. "Uğursuzluk getirmemesi için askerlik süresince askerden gelen mektuplar yırtılıp atılmaz, görülmeyen yerlere asılmaz." (K4). "Askerin gönderdiği mektuplar, o sağ salim döndüğ̈ zaman yakılarak ateşinde yumurta pişirilir ve askere yedirilir.” (K1). Yumurta "Canlının doğma olayını ilk olarak 
başlatan bir tohumu içermesi nedeniyle kendi kendini doğrudan açıklayan evrensel bir sembol olmuştur." (Ersoy, 2007: 559). Bolluk, bereket, doğurganlık, çoğalma ve bütünlüğü ifade eden yumurtanın, askerin kutsal görev yerinden gönderdiği mektupların ateşinde pişirilerek kendisine yedirilmesi oldukça anlamlıdır. Askerin mektupları, sevdiklerinden uzakta geçen günlerin hasretini yansitmakta olup sıkıntıların sona ermesi ve gencin kutsal vatan emanetini koruyup sağ salim dönebilme başarısı, yakılan mektuplarının üzerinde pişirilen yumurta ile kutsanır. Kendisine verilen görevi başarıyla yerine getiren asker, bireyleşim sürecini tamamlamış olup ruhsal bütünlüğe ulaşmıştır. Onun başarıs1, ödüllendirilmeyi hak etmektedir. "Bazı halk hikâyelerinde (Doğu Anadolu) de atışmada, diğer âşıkları yenen hikâye kahramanı, onların sazlarını alıp ateşe atarak üzerinde kaygana (yumurta) pişirir." * Bu örnekler bir işin başarıyla sonuçlanmasını kutlama, bereketi paylaşma anlamında yumurta-başarı bağını ifade etmektedir. Nitekim atışmada ustalığını ispatlayan âşık, bu eylem ile bileğinin hakkıyla kazandığı ödüle, diğerlerinin de çalışarak ulaşabileceğini mesajlar. Asker gencin aşama geçirip kendisini ispat etmesi, onun yeni bir aşamaya adım atmasına zemin hazırlamıştır. Yumurta ile ritüelleştirilen uygulamada, bireyleşen gencin, artık evlenerek aile kurma ve çoğalma zamanının geldiği sembolik olarak anlatılır.

Halk arasında yumurta kırma ile ilgili olarak farklı uygulamalara da rastlanılmıştır. "Elya/İlya aşiretinde nazara karşı korunmak için yumurta kırılır. Bu kırma işi fırlatılarak çarpması sağlanmak suretiyle yapılan bir kırmadır. Gelin yeni eşiğinin önüne ilk geldiğinde, yeni evin duvarına yumurta firlatılarak karlar ilk erimeğe başlayıp çifte çubuğa ilk çıkıldığı zaman öküzün boynuzuna veya alnına yumurta kırılır. Bu inanç ve uygulama Ağrı' da yaşayan Karapapak Türklerinde de vardır. Yumurta kırmanın nazardan koruyacağına da inanılır. Daha ziyade yaz başı hayvanlar hamdan/hamlıktan çıkınca onların alınlarında yumurta kırılır.” (Kalafat, 2012c: 91). Söz konusu örnekler, askerin mektuplarının ateşinde yumurta kırarak pişirme amacının, onu kem gözlerden korumak amacıyla yapıldığını da düşündürmektedir.

Farklı bir uygulama ise şöyledir: "Askerlik dönüşü aile tarafından un helvası yapılır. Akraba ve komşulara dağıtılır.” (K4). Askere uğurlanırken de yapılan benzeri uygulamada, unun kavrulmasiyla kokusunun etrafa yayılması sağlanır. Böylece, mitolojik dönemin iyi ruhları memnun etme inancının yanı sıra İslamiyet'ten sonra asker dönüşü ile yapılan iyi haberin çevreye duyurulması, şükür edilmesi ve birlikte yenilen helva ile mutluluğun, ağız tadının paylaşılarak artmasını dileme amacı gerçekleştirilir.

\footnotetext{
* Prof. Dr. Esma Şimşek'in ders notlarından alınmıştır.
} 
Doç. Dr. EBRU ŞENOCAK

\section{Sonuç}

"Mitoloji insanlık kültürünün ilk dilidir." (Köktürk, 2017: 283) Mitolojiler, ilk zihinsel deneyimlere bağlı olarak anlamlandırılan doğa, insan ve topluma dair gerçekliklerin edebî ifadesidir. "Mitosu üreten bilinç gerçekten gelişmiş ve soyut düşünebilen, dolayısıyla gelecek tüm çağlara bilinçlerini keşfetmeleri için sırlar sunacak kadar çağlar üstü bir zihindir.” (Köktürk, 2017: 283). Tarihin kaydedilemediği bir dönemi bizlere sunarak geçmişimizi öğreten bu kutsal anlatılar, ritüellerin varlığında sembolik anlamlarıyla yaşamaya devam etmektedir.

Anadolu'da ve Türk dünyasında olduğu gibi Baskil ve çevresinde tespit ettiğimiz örnekler, ortak bir kültür birliği oluşturmaktadır. Askere yollama ve askerden karşılama esnasında halkımızın un, simit, ekmek, su, yumurta, bayrak vb. ile yaptığı uygulamalar bolluk, bereket, bütünlük, kutsallık duygularıyla ata kültünü bugünde güncellemekte ve kültürel belleği canlı tutmaktadır. Kutsallık ve inandırıcılık ile her dönemde yeniden üretilen mitolojik anlatılar, toplumun katılımıyla geçmiş ve gelecek arasında bağ kurarlar. Bizi millet olarak bugünlere getiren sahip olduğumuz ve koruyabildiğimiz değerlerimizdir. Kimlik bilincimizi belirginleştiren öz değerlerin kutsallığ 1 halk arasında gelenek, tarih, dil, din, kültür, vb. değerlere bağlılık ile yaşatılmakta olup mitosların ve ritüellerin canlandırılmalarında sembol diliyle ifadesini bulur. Mitolojik dönemin etkilerini taşıyan uygulamalar, halkın ata kültüne bağlılı̆̆ inancının etkisi ve İslami inanışların varlığı ile şekillenmiştir. Bu anlamda toplu eylemlerle kutsallaştırılarak kültürel bellekte yaşatılan geleneklerin, inanış-mitoloji ilişkisiyle değerlendirilmesi ve sembollerin anlamlandırılması gerekmektedir.

\section{KAYNAKCA}

\section{Yazılı Kaynaklar}

Artun, Erman (2000), “Adana'da Asker Uğurlama Karşılama Törenleri Asker Ağıtları, Türküleri, Şiirleri, Manileri”, Milli Folklor, Yı1: 12, Sayı: 47, s. 41-48.

Asmann, Jan (2001), Kültürel Bellek/Eski Yüksek Kültürlerde Yazı, Hatırlama ve Politik Kimlik, Ayrıntı Yayınları, İstanbul.

Bachelard, Gaston (2006), Su ve Düşler/Maddenin İmgelemi Üzerine Deneme, (çev. Olcay Kunal), İstanbul.

Bachelard, Gaston (2008), Uzamın Poetikası, (çev. Alp Tümertekin), İthaki Yayınları, İstanbul.

Çelepi, Mehmet Surur (2017), Türk Kültür Evreninde Toy Denizli Örneği, Kömen Yayınları, Ankara.

Çetintaş, Mustafa (2010), Arıcak'ın Bükardi Beldesinden Derlenen Halk Edebiyatı Unsurlarl, Elazığ. (Fırat Üniversitesi İnsani ve Sosyal Bilimler Fakültesi Türk Dili ve Edebiyatı Bölümü Lisans Tezi).

Eker, Gülin Öğüt (1998), “Türk Kültürü İçinde Geleneksel Bolu Evlenme Âdetlerinin Yeri”, Millî Folklor, Y1l: 10, Sayı: 40, s.15-30. 

bul.

Eliade, Mircea (2003), Dinler Tarihine Giriş, (çev. Lale Arslan), Kabalcı Yayınları, İstan-

Ersoy, Necmettin (2007), Semboller ve Yorumlarl, Dönence Yayınları, İstanbul.

Gökhan, Halil (2009), Semboller, (Editör), Dharma Yayınları, İstanbul.

Kalafat, Yaşar (1995), Doğu Anadolu'da Eski Türk İnançlarının İzleri, Atatürk Kültür ve Tarih Yüksek Kurumu Atatürk Kültür Merkezi Yayını, Ankara.

Kalafat, Yaşar (2006), Balkanlardan Uluğ Türkistan'a Türk Halk Inançlarl, C. III-IV, Berikan Yayınevi, Ankara.

Kalafat, Yaşar (2012a), Türk Halk İnançlarında Renkler, Berikan Yayınevi, Ankara.

Kalafat, Yaşar (2012b), Türk Halk Inançlarında Beslenme, Berikan Yayınevi, Ankara.

Kalafat, Yaşar (2012c), Aşiretlerde Mitolojik Bulgular, Berikan Yayınevi, Ankara.

Kalafat, Yaşar (2013), Bozulus Türk Kültür Coğrafyasında Karşılaştırmalı Halk İnançları, Berikan Yayınevi, Ankara.

Kıyak, Abdulkadir (2005), Baskil ve Çevresinde Yaygın Halk Inanışları, Elazı̆̆g, (Fırat Üniversitesi Sosyal Bilimler Enstitüsü Felsefe Ve Din Bilimleri Ana Bilim Dalı Dinler Tarihi Bilim Dalı Yayımlanmamış Yüksek Lisans Tezi).

Kızılaslan, Caner (2019), Elazı̆̆ Baskil İlçesi Monografisi, Niğde, (Niğde Ömer Halisdemir Üniversitesi Sosyal Bilimler Enstitüsü Türk Dili Ve Edebiyatı Anabilim Dalı Yayımlanmamış Yüksek Lisans Tezi).

Köktürk, Milay (2017), Toplum ve Kültür, Ötüken Yayınları, İstanbul.

Öz, Duygu (2015), Elazığ Folklorundan Örnekler, Elazığ (Firat Üniversitesi İnsani ve Sosyal Bilimler Fakültesi Türk Dili ve Edebiyatı Bölümü Lisans Tezi).

Özkan, Ali Rafet (2003), Dinlerde Kurban Kültü, Akçağ Yayınları, Ankara.

Parlakkaya, Ezgi (2020), Elazı̆̆ Folklorundan Örnekler, Elazı̆̆. (Firat Üniversitesi İnsani ve Sosyal Bilimler Fakültesi Türk Dili ve Edebiyatı Bölümü Lisans Tezi).

\section{Sözlü Kaynaklar}

Aşağıda kaynak şahıslar hakkında bilgi verilirken şu sıraya bağlı kalınmıştır:

a. Adı Soyadı, b. Doğum yeri, c. Yaşı, ç. Öğrenim durumu, d. Mesleği, e. Derleme tarihi. 2019.

(K1) a. Perihan Altaca, b. Elazı ̆̆/Harput, c. 85, ç. İlkokul mezunu, d. Ev hanımı, e.08.07.

(K2) a.Şemsi Erişir, b. Altıyaka Köyü, c. 65, ç. , d. Ev hanımı, e. 28.12.2019.

(K3) a.Aysel İlhan, b. Baskil, c. 50, ç. İlkokul mezunu, d. Ev hanımı, e.01.03.2020.

(K4) a.Osman Kalkan, b. Elazı ğ, c. 82, ç. İlkokul mezunu, d. Emekli memur, e.01.03.2020.

(K5) a.Nursel Odabaşı, b. Baskil, c. 54, ç. İlkokul mezunu, d. Ev Hanımı, e.01.03 